\title{
Welfare and Social Capital in Linköping, 1600-1620
}

\author{
Annika Sandén
}

This article deals with early seventeenth century local government, both the secular and religious, in order to present a thesis investigation of that period's concepts of "the good society", and the strategies that were used to achieve and retain this ideal. ${ }^{1}$ The modern concept "welfare" is used as an analytical tool, not in spite of, but rather due to its modern connotations, because it opens up the field for questions concerning the differences and similarities between us and these people who lived in the past. Perhaps the social transformation of the latest centuries has only created new premises for a striving that is universal and common to all mankind?

Current social scientists often speak of welfare in terms of participation, influence and creation of a society in which people have confidence in formal institutions. In other words this is what usually is referred to as a social "glue", a social capital. ${ }^{2}$ An important quest for welfare is how to integrate a fundamental base of trust between different groups of people in society, which differ in lifestyles, working patterns and perhaps identifies themselves in diametrically different ways. In the end, society is build of compound human social relationships. Formal institutions are obviously based on single human individuals. Studies in welfare can therefore benefit from analysis that separates those mechanisms that create, nourish and maintain relationships, both horizontal and vertical. In that way a social capital can be tracked and in what way and for whom it might be beneficial. ${ }^{3}$

Along with the dimensions of power that lies in the terms of social capital, it can also be seen as a collective and societal resource. ${ }^{4}$ Robert D Putnam speaks of a strong socialt kapital - bonding social capital - to define that sort of capital that has got the

1 This article is based on the dissertation Stadsgemenskapens resurser och villkor. Sambällssyn och välfärdsstrategier i Linköping, 1600-1620 (The Towns sense of Commuity. Views of Society and Welfare Strategies in Linköping 1600-1620), (Linköping 2005).

2 See Simon Szreter, "The state of social capital. Bringing back in power in politics and history", Theory and Society, (2002); Michel Woolcock, "Social capital and economic development: Toward a theoretical synthesis and policy framework", Theory and Society 1998:27 (1998)

3 Woolcock, (1998), p. 184ff.

4 J. Sundin \& S. Willner, "Social stress, socialt kapital och hälsa. Välfärd och samhällsförändring i historia och nutid", Sambällsförändring och hälsa. Olika forskarperspektiv. (Stockholm 2003), p. 21. 
most power implications. ${ }^{5}$ This variant tends to emerge in groups whit people who identify themselves whit one another, politically, socially and culturally. But, according to Putnam, a social capital can grow to people outside the main group. This can create trustful relations between more. This kind of extended social capital is according to Putnam crucial in creating democracy and economic growth. This is called a bridging social capital. This variety emerges in heterogeneous groups, but where there is a common interest. Putnam speaks of voluntary associations as the best forms to get this kind of social capital. ${ }^{6}$ Putnam does not see that the state has got this ability. ${ }^{7}$

Marjorie K McIntosh does not see that the voluntary dimensions are necessary in order to get and maintain a beneficial social capital. According to McIntosh, most people in the early modern period were involved in a broader societal goal, just as they at the same time manifested them self trough economic competition and self interest of different sorts. There is not necessarily so, according to McIntosh, that a good beneficial societal resource derives from voluntary associations, from the civil society or from modern democratic institutions. It can just as well emerge from the local early modern - undemocratic - formal institutions, such as the municipal court or the cathedral chapter. ${ }^{8}$

Simon Szreter stresses that a societal social capital ought to emerge from a broader common interest. In contrast to Putnam, Szreter points out that it is the institutions only that can bring about trust in a larger extent. Simon Szreter and Michel Woolcock speak of a linking social capital, in order to describe a variety of social capital that derives from formal institutions. Bo Rothstein has emphasized the same position - a social capital that integrates society emerges in networks which in turn emerges from values on care, equality and support for those in society that needs it the most. ${ }^{9}$ This article shows that in the Swedish early modern town of Linköping, social capital was derived from the clearly self-interest of those in the local "elite", as well as a consequence of articulated evaluations of the local society as a whole.

5 P. Bourdieu, "The Forms of Capital", Handbook of Theory and Research for the Society of Education, (London 1986); R. D. Putnam, Bowling alone : the collapse and revival of American community, (New York 2000), passim; Sundin \& Willner, (2003), p. 21.

6 Putnam, (2000), p. $15 \mathrm{ff}$.

7 Putnam (2000); Sundin \& Willner, 2003, p. 22.

8 M. K McIntosh, "The Diversity of social capital in English communities, 1300-1640 (with a glance of modern Nigeria)", Rothberg ed. Patterns of social capital: stability and change in historical perspective, (Cambridge 2001), p. 123ff.

9 B. Rothstein, Democracies in flux: the evolution of social capital in contemporary society, 2002; Restructuring the welfare state: political institutions and policy change, (Oxford 2002); Szreter, (2003), s 6ff; Woolcock, (1998), p. $185 \mathrm{ff}$. 


\section{Welfare Strategies in an Early Modern Swedish Local Society}

The intellectual world viewed the good society as an organic whole. Justice and wellbeing were not a question of individual rights, but rather were found in corporative bodies in which differences together created hierarchical harmony and order. ${ }^{10}$ Luther's Haustafel, which was printed in the hymnbook, stated each person's given place inside the household, and in society. This normative description of positions and relationships seems to have corresponded with the existing social order. ${ }^{11}$ The Household, thus, was a symbol of the good society, assumable because of its significant importance for the survival of the individual. Local authorities do not express any concept of development or a utopia of change. They did not seek to redistribute material resources or systematize support for specific vulnerable groups. A fundamental welfare strategy was thus to fit people into households within which they could support themselves. This was also what the municipal court and the cathedral chapter primarily worked with. What was the goal, if it was not change? The institutions reestablished bonds of friendship and restored relations. It was a view of society that stressed conservation, with its foundation in an idea of the static good, as previous research has shown was the case in the world of the learned.

How was this ideology on society's welfare expressed locally in a town such as Linköping, where order in local society lay in the hands of a local "elite" that lacked democratic legitimacy, was formed by local interests, and was administered by laymen? Did the ruling authorities such as the municipal court (rådsturätt) and the cathedral chapter (domkapitel) bear the stamp of group interests? Were marginal groups dependent on alms from those better off, or was poor care and support for selfhelp available in institutionalized form? Further, how was order achieved in local society, both on the normative level and in practice? What was regarded as the good society? Who defined what was considered good? For whom was it good? What strategies were used to achieve and attain this goal? These questions shall be addressed below, first, though, a few demographic remarks.

Linköping made a relatively small society where people lived close to one another. The material resources were generally small, and people needed the support of one another in matters both large and small. The household and the parish were the individual's most important spheres for material, spiritual and social security. Linköping was the capital of the diocese and therefore was not as every other town, on behalf of functions and educated people. The size, though, was just about average, with approximately 1200 inhabitants. The burgers, the church people and the staff of the castle were social groups in local society which probably made households that

10 L. Runefelt, Hushållningens dygder. Affektlära, hushållningslära och ekonomiskt tänkande under svensk stormaktstid, (Stockholm 2001); K. Stadin, Stånd och genus i stormaktstidens Sverige, (Stockholm 2004); L. Roper, The Holy Household. Women and Morals in Reformation Augsburg, (Oxford 1991).

11 H. Pleijel, Hustavlans värld: kyrkligt folkliv i äldre tiders Sverige (Stockholm 1970). 
were economically and socially stabile. Women, which were legally independent, belonged to the social group of their fathers or husbands. Beside these groups there was another, which contained these people that made their living on much more occasional grounds, as day workers and handymen. All these groups, despite all differences between them, were lawful inhabitants and made households and had their rightful and specific place on a pew in church and thus a place in the parish in the cathedral benches. The persons who had a legitimate home belonged to one of the town's established households and in that way were part of a recognized social group. As such one could claim the access of facilities in town that people tended to need in order to supply for themselves and reassure their security, materialistic and emotionally. Those were the ceremonies in church, as to baptize the newborns, to bury the dead and to get access to the holy communion. Another institution that seem to have been of great importance was the municipal court, which was the place for making economic transitions, as well as justice and re-establishing damaged relationships. As a legal inhabitant one also had the rightful access to the town mill and wells.

The main difference between people was thus, assumedly, between these groups together on the one hand, and the so called "loose people" on the other. This group comprised poor strangers, often unwed mothers. As they did not have access to a functional self suppliant household they begged, and perhaps stole or were prostitutes to support themselves. In this way they were a fundamental threat to the general order. Along with poor males, who often were accused and judged for theft, they were looked upon with great suspicion. ${ }^{12}$

\section{Tranquility and Order}

In the activities of both the chapter and the municipal court, an active evaluation of tranquillity and concord can be seen not only towards this group but also to people in general. Order and balance appear to have been the overriding goal for the local institutions in Linköping around the turn of the century 1600 . This tranquillity was supposed to leave its mark on all relations, both private and public: children should obey their parents, the wife her husband, and the hired hand his master. The parishioners should obey their priest and gather in the church to express their common thanks. The patriarchal order also implied that even those who were subordinate had certain rights to claim. The priest was to lead the parish by means of sermons and caring for souls. The master bore the ultimate responsibility for the well-being of the

12 On poverty and rejection from society, see R. Jütte, Poverty and Deviance in Early Modern Europe, (Cambridge 1994). 
members of his household; the person in charge of the poorhouse (hospital) was the master of the poor and was responsible for those who lived there. ${ }^{13}$

To guarantee peaceful relations in local society in the long run, those active in the local institutions had to publicly pledge one another friendship and had to shake hands before the town council and the mayors. This was a part of settlements and sentences, for example, the command to want to treat one another well, to harbor love and friendship for one's brother, as it stands in the records in the settlement between a nobleman and his priest. To place a high value upon peace between neighbors was a way to work for the good of all. When a husband and wife under penalty of a fine had to agree to live in peace and harmony with one another, it was not merely a wellintentioned wish on the part of the cathedral chapter, but rather a demand that had been formulated. It was a kind of suspended sentence, because otherwise they would have been sentenced to banishment from the parish.

\section{Who Was in Charge?}

It was the mayor and the councils who carried out administration and justice in the town, even if the cathedral chapter dealt with similar cases in their meetings. The social order was a question for both the secular and spiritual authorities. These institutions, the municipal court, the cathedral chapter, and the parish council held, the society together. The basis for secular justice was found in Christopher's Law of the Land and the Town Law of Magnus Eriksson. ${ }^{14}$ The cathedral chapter followed the canon law of Laurentius Petri. ${ }^{15}$ The meetings of the parish council were determined by what happened in town and by what the members of the parish council regarded as being of importance and interest. The municipal court and the cathedral chapter were arenas to which people turned with matters with which they wanted help. Especially the municipal court met to deal with the most disparate kinds of matters, such as repairs to the cathedral, economic conflicts or actual criminal cases. The municipal court even chiselled out the guiding principles in very intimate relations and the conditions in individual marital relations. Local society was thus formed both practically and normatively in negotiations between the formal leadership of institutions and the people who used these functions.

There was consensus on what was regarded as threats to the order of the town. The cathedral chapter and the municipal court had the same fundamental attitude in all

13 S. Ozment, When Fathers Ruled. Family Life in Reformation Europe, (Cambridge 1983); Roper, (1991). 1966).

14 Magnus Erikssons Stadslag i nusvensk tolkning. A.. Holmbäck \& E. Wessén, (Stockholm

15 Laurentius Petri,, "Oeconomia Christiana. Om Christeligh Husholdh och huad huario person eientligh effter gudz befolningh i huusholl tilkommer", Skrifter frän reformationstiden 5, (Stockholm 1897). 
their activities. Both worked to maintain households and thus shared an idea about how society should best be organized. The composition of local government was such that the bishop, mayor and others from the spiritual and secular authorities were probably acquainted with one another. The activities of the parish council show that the political leadership was primarily formed by a group of men from among the burghers. Sometimes it was even the same men who sat in both the parish council and the municipal court. This probably was of significance for the similarities that have been found. ${ }^{16}$ The institutions had a similar way of striving for their goals, but that will be accounted for below.

The activities of these authorities were shaped by the concerns of the local society. Seen from the perspective of the formation of states, the business of the formal institutions in Linköping around the turn of the century 1600 sheds light upon local political culture and administration before the bureaucratization of the country's administration. ${ }^{17}$ It was only the sheriff, a crown official, who represented the interest of "others" in the town, and at the same time the state left very few tracks in the records. After more than half of the period studied had passed the court of appeals was established in 1614. At the end of each year the court of appeals was to have a copy of the records of the lower courts in order to be able to check on whether or not the administration of justice was in line with the law texts. Because there is no evidence that court of appeals criticized how justice was carried out in Linköping, it can also be assumed that even on the national level, it took time to realize the function of the court of appeals. ${ }^{18}$ The 1608 amendment to the printed version of the law of the land with its drastic increase of sentences, for example, for sexual crimes, has not left any traces in practice. No one was sentenced to death for adultery, nor for incestuous crimes. When it came to the national canon law, the synod was the institution that implemented this law in the parishes. Both the cathedral chapter and the parish council referred sometimes to new regulations, as, for example, when the parish council referred to the Örebro meeting of 1616 when it was decided that a woman who had lost her virginity could not bear a bride's crown when she married.

Local government thus set the town's agenda, that is, it determined what was important, which groups were problematic, and how they were to be dealt with. ${ }^{19}$ Those

16 Sandén, (2005), p. $85 \mathrm{ff}$.

17 Eva Österberg have emphasized that the relationship between local society and the state shall be understood in terms of integration. E. Österberg \& S. Sogner, (eds.) People meet the Law. Control and Conflict -handling in the Courts, Universitetsforlaget, Oslo (2000); Österberg, "Bönder och centralmakt I det tidigmoderna Sverige. Konflikt - kompromiss - politisk kultur" Scandia 1989:1 Börje Harnesk, on the other hand, have stressed the conflict aspects, B. Harnesk, "Något om den lokala självstyrelsens problematik under 1500-och 1600-talen", Individ och struktur $i$ historisk belysning: festskrift till Sune Akerman, T. Ericsson \& G. Guillemot (eds.), (Umeå 1997)

18 A study of Vadstena, ca 1610-1630, shows that the transition to a more faithful application of the law took time to carry out. "Handlingsnormer och rättskipning i det tidigmoderna Vadstena", Socialhistoria i Linköping nr 1, (Linköping 1997), p. 33.

19 Sandén (2005) p. 85 ff. 
who were different were strictly excluded by the parish council, such as unknown strangers and those who did not live Christian, God-fearing lives. Only if strangers could show who they were, how they made their living, they could participate in the religious service and in the life of the community. It is not possible to know who actually attended and took part in the parish council meetings. Because the alienating attitude that the parish council showed was probably not held by people in general, the parish council may not have been representative for the town's population. There were thus groups in the local society that had little or no insight into the decisions that were made about matters that pertained to them. That was, for example, true of unwed mothers. The fact that the parish council largely consisted of those men who also were in charge of the municipal court, that is the mayors and the council, the city can be said to have been run by men. When the burghers did not work via their membership in the council, they were either merchants or artisans. Because the municipal court was the arena in which the market was regulated and a forum for information and decisions in economic matters, it should be possible to assume that the municipal court served the interest of the burghers. Still, did the town council, the parish council and the cathedral chapter in their respective fields of action and decisions work for the common good or for the special interests of their respective groups?

\section{... and Who Did Benefit?}

The members of the town council were chosen from among the trusted burghers of the town. For the person who belonged to the burghers it was, generally speaking, a resource to invest in and to defend. The municipal court was an arena where membership in the town's male social and economic core was manifested. It was in the court house that they assured themselves of the confidence of the others. This took place in ritualized form. If a burgher was suspected of having committed a crime, which sometimes happened, the municipal court could "render the act harmless." This did not mean that the burgher was acquitted, but rather that it was of significance who the suspect was in local society. When a burgher committed a crime, a settlement was usually mediated and a lower sentence was handed down than what the law prescribed for the crime in question.

The municipal court was both an institution and an arena. Here economic transactions were sanctioned, and decisions were made concerning the practical order of things in the town, for example, when the wells were to be repaired, which burghers would do this, and how much they should be paid. The municipal court also had a number of rituals which balanced social relations. By swearing one another honor and peace, order could be reestablished and both parts could leave the court house with their honor intact. The plaintiff won his case and received compensation, while the condemned could atone his crime through the punishment and later regain his former 
position. The practice of the court favored people who had the confidence of those in the center of power. When serious crimes were committed, hired men, female servants, soldiers and others with lower social positions, who had few or no connections to the burghers' circle could have difficulty in availing themselves of the rights that the law gave to a suspect, such as the evidence provided by an oath because its foundation was the town council's and the mayors' recognition of the status of those in local society who swore the oaths.

In order to be able to utilize the rituals of the town council it was also important to have a capital of trust. Even in the cathedral chapter a personal capital of trust could play a role. In particular women could have much use for a man with a position of trust who spoke on their behalf. When a woman wanted to get a divorce from her abusive husband, it was of significance that she had the support of the province official person without means in the poorhouse could be represented by the councilman that was in charge of the poorhouse.

People who stood outside these corporations were threatened by marginalization. ${ }^{20}$ Those persons who did not have a permanent residence, who supported themselves by begging, who stole or who committed adultery were regarded by all of the institutions as a threat to order in local society. Unwed mothers and "vagrants" had few, if any, connections with these arenas where decisions were made about their conditions.

\section{Actual Welfare Strategies}

When people lived in a self-sufficient household headed by a wedded couple, the foundation for the Christian social order was laid. This also was the premise for basic economical survival. Local society, however, had to take a stand to the fact that neighbours quarrelled, that certain people were not able to support themselves, that unmarried women became pregnant, that couples want to divorce, and that the tranquil order that was the major objective simply would not be reached. People lived in close proximity and were dependent on one another. It was a society that generated conflicts. The conflicts between neighbours, infringements and malicious rumours threatened this order. Each and every one was supposed to carry out their assigned tasks in the household and in local society under stable hierarchical conditions. Just as earlier research has pointed out, the primary goal was to maintain an organic whole, where people could live in peace and harmony and go about the task of making their own living. ${ }^{21}$ The formal institutions, however, hade numerous strategies for maintaining both order and a functioning local society.

20 Jütte, (1994).

21 J. Sundin, För Gud, staten och folket. Brott och rättskipning i Sverige 1600-1840, (Lund 1992); Stadin, (2004). 


\section{The Principle of Maximizing Utility}

The importance that the intellectual world placed on the household had a practical application in Linköping. Local government expressed the same basic position in its actions as the learned did in their writings, but government showed flexibility and variation. The overriding goal in the practical actions of local government was to fit people into households. In order to maintain the hierarchical and patriarchal order in the household and in local society demanded compromises. The municipal court and the cathedral chapter acted on the basis of the purely pragmatic principle that whatever encouraged peace and harmony among the inhabitants was good. This was true on all levels-between parents and their children, between marital partners, between the town council and the sheriff. When the cathedral chapter divorced people who could not live together in spite of the fact that there was no legal motivation, I see it as a way of optimizing utility. From both the church and the marriage partners, as well as parents and neighbours, there should have been an interest in building up a marriage that could endure. In spite of the law both the cathedral chapter and the municipal court gave a great deal of room for the specific circumstances of the individual case. ${ }^{22}$ The law was not absolute, but rather seems to have served as a guide. ${ }^{23}$ When the cathedral chapter negotiated with the persons who had sought help in marital and divorce cases, the content of the marriage was formed. In the same way the men of the parish formed part of the content of the priest's role. This was the pragmatic effect of taking into consideration the wishes of people. The flexibility in the way in which the cathedral chapter operated is seen not as arbitrary or random, but rather served a long-term rationality of stability.

The social order that was the goal thus had its foundation in a kind of maximization of utility, sometimes at the expense of the individual. The fact that people lived close together and that the members of the town council and the inhabitants of the town were integrated with one another, was probably both a premise for the flexible treatment and a product of it. The closeness made it possible to take into account the specific circumstances in each case and how it could best be resolved. This same proximity demanded a flexibility of action. The mayors and the town council both could and were forced to take into consideration the circumstances of those involved. It was a strategy for order. The decisions handed down by the municipal court and the cathedral chapter were thus based first of all not on individual rights and the interests of individuals, but rather on the collective good. The large range of action in the dealings of the courts could, on the other hand, give the impression of quite the opposite. In every case the very specific circumstances of

22 See M. Lennartson, I säng och säte. Relationer mellan kvinnor och män i 1600-talets Småland, (Lund 1999).

23 This seems to have been the characteristics of justice in Early Modern Europe, B. Lenman \& G. Parker (eds.) Crime \& the Law. The social History of Crime in Western Europe since 1500, (London 1980); J. Sharpe, Crime in Early Modern England 1550-1750 (London 1984). 
the actual partners were carefully considered. The sentence, for example, was adjusted to the ability of the person fined to pay, settlements were adapted to the circumstances of those involved, and the very intimate conditions in marital cases bear witness to the fact that every case was individual, and that, even if the ultimate utility should serve the collective, consideration was taken to the wishes of people. This implies that the courts' actions were at the same time individualistic.

\section{Banishment and Incorporation}

People were assembled in church for "enjoyment," to assure themselves of spiritual and worldly well-being, to demonstrate their belonging, and to guard their positions. At the same time as institutions, using more or less heavy-handed methods, "drove" people into households and church pews, the same institutions could also prevent people from gaining access. ${ }^{24}$ The cathedral chapter sometimes forbade someone from remarrying. ${ }^{25}$ Forbidding marriage or noting the "correct" marriage was an expression of the same demand for conformity that characterized the municipal court and the parish council. The church and the town council established the norms of the ordered society by sanctioning access to these spheres that created resources.

Because unwed mothers were usually the target for the institutions of the church that dealt out punishment, it was often women who were excluded. ${ }^{26}$ It is not possible to know how many were punished in this way. Exclusion was a punishment for the person who suffered from it. Exclusion from the parish probably also denoted an alienation in a broader sense. It was the same as being excluded from society. From the perspective of the leadership it was also a way of cleansing the parish of "disruptive elements."

In addition to the municipal court, the parish council guarded the borders of local society closely and were skeptical to those who did not have proper papers as to who they were and what their errand was in town. When the parish council administered a fine for an infringement, there was sometimes also the threat of banishment from the parish if the same crime was repeated by the same person. If a third crime of the same sort was committed, then the person would be banished from town. ${ }^{27}$ To be banished from town was thus the most stringent form of banishment.

Execution was a punishment for especially serious crimes. But it was of importance who the criminal was. ${ }^{28}$ Those who were condemned to death by the municipal court were all strangers in town and thus lacked important networks. They belonged to the

24 Sandén, (2005), p. $217 \mathrm{ff}$.

25 Sandén, (2005), p. 180ff.

26 Cf. M. Lindstedt Cronberg, Synd och skam. Ogifta mödrar på skånsk landsbygd 1680-1880, (Lund 1997).

27 Sandén, (2005), p. $180 \mathrm{ff}$.

28 Sundin, (1992), p. $455 \mathrm{ff}$. 
group "vagrants" that institutions tried to get rid of. A man who was condemned to death because of his thefts, had luckily one of the town's most powerful merchants as his father, a man who had earlier been mayor, and who was one of the men in the bishop's circle. ${ }^{29}$ The sentence was not carried out. Instead the condemned had to "go underground" for a while. Banishment and execution appear to have had the same goal: the criminal had disturbed the order and had to be removed.

Integration was another method of creating order. Young women and men were not supposed to "stand on their own," but rather to take posts as female servants or hired man and thus assume a legitimate place in the social order. The town council tried as well as they could to find places in households for the town's unmarried mothers, perhaps as servants somewhere, or even with the father of the child. In other words the local institutions tried to minimize the number of marginalized persons. Banishment, integration and execution were thus strategies with the same goal. The person who was banished from town no longer existed, as long as the person did not come back-only to be banished once again. Outside the town there was little protection for the individual. This shows that the security of the individual was dependent upon affiliation with the "communities" within the town.

\section{Ritualized Honor}

Honour, by regulating actions, acted as a cement between people both vertically and horizontally, and it was also used by the local institutions as a strategy for the confirmation of the norms of order. Honour was personal capital that assured access to the most important communities. ${ }^{30}$ Honour was thus something to defend. Personal reputation was closely guarded and the municipal court punished severely those who spread rumours. By doing so, these formal institutions reaffirmed the practical social value of honour. Honour had a different appearance when viewed vertically, that is the merchant had another range of action than did the hired man, but horizontally there was consensus concerning this resource creating function.

To simplify, it can be said that the local institutions sustained the significance of honor. The ceremonies of the church manifested honor. In addition to the religious benefits, there was also a social dimension in the ceremonies of the church. Properly carried out in the presence of neighbours, people invested in social and material security. Marriage, baptism and the reception of the mother in church after childbirth were primarily a visualization of women's honour. For those who for various reasons were not included in this norm, for example the unwed mothers and their children,

29 Sandén, (2005), p. $118 \mathrm{ff}$.

30 Ch. E. Sandmo "Aeren och aerekrenkelsen", Normer og social controll: ca 1550-1850 Domstolene i samspill med lokalsamfunnet Rapport II, det 22. nordiske historikermöte (Oslo 1994), p. 82; M. Dinges, "Die Ehre als Thema der Stadtgeschichte. Eine Semantik im Übergang von Ancien Régime zur Moderne", Zeitschrift für historische Forschung 16,( 1989). 
there was little room for them on the established arenas of security. Both men and women were suspicious of sexuality outside the bonds of marriage, perhaps because they witnessed the poor living conditions that an illegitimate child could entail. Perhaps it was such a woman, outside the church in both a physical and social meaning, that the other women wanted to avoid becoming, or be suspected of being. Sexual intimacy was an axle around which norms concerning social order were reproduced, within which marriage was the smallest element. By sanctioning the right to the most important community by means of the peaceful behavior, prescribed by the local institutions, honour was made a catalyst for a peaceful community. When the right to sexual intimacy was conditioned in this way, there was a social incentive to keep to the rules. This ritualized honor balanced relations and in this way regulated the norms of the ordered society. ${ }^{31}$

\section{Appointed Guardians}

The individual burgher invested in his membership in the community by performing those services that were assigned to him. When he did this, such as serving as an appointed guardian, links were created between various groups in society, whereby the matter came to be of interest to more than those involved from the beginning. Perhaps the individual burgher had visions for local society as a whole, or perhaps he performed those services that the town council had assigned to him because it secured his position within the circle of the town council. Whatever the reason, it was apparently an effective strategy to realize settlements and carry out the decisions reached by the municipal court. A successful arrangement was one that favoured all parties. When the municipal court appointed guardians to take responsibility for someone who was to be released from jail, a greater number of people became interested in a successful reintegration. The dominant system of responsibility had the same consequences. The master of a household who allowed his hired hand to be out at night or the master craftsman who could not keep his journeymen in order could be sentenced to make compensation for the damages that the members of their households may have caused. By placing responsibility not only upon the hired man, but also upon his master, the crime of the hired man became the business of more than just himself. From the mayors, councilmen, masters of the households, and even criminals, chains of reciprocal dependence were created - the mayor and the council wanted to create social order, the guardian strengthened his membership in his group, the criminal sought his freedom, and the sum of the individual elements meant that order was restored.

The question is how much intent was involved in the actions of the municipal court and the cathedral chapter. Was the system with the appointment of a guardian a kind of social engineering or should it be understood from the perspective of mental-

31 Sandén, (2005), p. $213 \mathrm{ff}$. 
ity? The one does not exclude the other, but I perceive that phenomena such as including, uniting and linking together were part of that period's way of thinking. Strata, social position and groups were central concepts in the intellectual life and even in the practical life of the day. Individuals were always part of a context, included within various functions and parts which had what were apparently different values, but which together comprised a whole. People should be part of a household: marital partners should be united, unwed mothers integrated, and female servants and hired men should get jobs. The person who was not included moved through a vacuum ideologically and practically.

\section{The Good Parish}

When people lived in marriages or in a household, just as the priest preached in his sermons, God's order was preserved. As canon law prescribed, and as the cathedral chapter also had the scribes articulate in the records, the regulations concerning marriage were also a way to safeguard God's protection. Extramarital relations displeased God. The whore was the work of the devil, and the guilty one had to be returned to God's good order.

In the same way the religious punishments, in addition to the punishment itself, can be seen as an important welfare strategy. The individual by means of his crime had angered God. By means of a ritual of forgiveness with elements of shame and disgrace the guilty person could show his atonement, be forgiven by the priest and the parish, and be reunited with the parish again. The ritual thus restored stability between God and the congregation. ${ }^{32}$ To recreate order was thus not just a question of a practical, secular order, as when the members of a household lived in complete harmony according to the prescribed hierarchical order, but also a way of appeasing God. If God liked what he saw, then perhaps he would rest his hand over the congregation. When all groups in local society gathered in the religious arena - young and old, nobles and servants - a godly social order was visualized. Everyone was needed for that. This was not something that the bishop and the cathedral priest could fix themselves within the churchly arena. When the congregation gathered in the church in a common ceremony, a stable relation was established between God and the congregation. Then there was reassurance of His protection against plagues, war and diseases, and for love, happiness and well-being. To placate God was a collective resource where the individual's interest in the functions of the parish was consistently subordinated to or ran parallel with the formal local institutions. It is in this way that I interpret the coercion of the church and its threat of punishment to the person who placed himself outside the congregation.

32 Sundin, (1992), p. $127 \mathrm{ff}$. 
The local government thus tried to formulate the conditions for welfare by creating the premises for two important spheres - the home and the parish. The question is whether this also applied in the countryside as well. Hypothetically the fact that the bishop and the cathedral chapter were found in the town and that the cathedral chapter also participated in the parish council was significant for the great value that was placed upon religious dimensions in the striving for welfare. Conditions may have been different in other towns of similar size, but where the bishop and the cathedral chapter were lacking. The residents of the town of Linköping probably also had significance for the formation of institutions, because through their problems they contributed to the creation of institutional praxis. Because there is no corresponding research for the countryside, or for another town, it is difficult to draw any general conclusions. Generally speaking, this manner of solving conflicts can be placed in a broader context, for example, pragmatism in the cases concerning marriage. ${ }^{33}$

\section{Social Capital}

Thus, for those who were "on the inside" resources were available. In the town were found material resources such as wells and gristmills, and the community of the parish and the municipal court. Most people were excluded from the ranks of decision-makers and had little or no possibility to influence the decisions that were made concerning their interests, such as the unwed mothers, hired hands and female servants, even though the town council protected the households of the burghers by safeguarding the town's privileges. The town's leadership was not a democratic organization. It has been shown that the strategies that were used were built up around the common norms of honour and belonging. The strategies that were used created a closely-knit society. People who lived there needed to be able to depend on one another. Did they? People used the institutions in the most different ways and apparently believed they could be useful. There existed what present-day social scientists and social economists call social capital.

The case with Brita and Måns can illustrate how good social capital could consist of various elements that do not necessarily have to be rooted in the common interest, but how personal interest can be used as in order to get a collective benefit. A collective resource might emerge out of a chain of several individual actors with self-interest and collective interests. By getting appointed guardians a resource was linked to the couple, who obviously did not have other beneficial networks. This is there fore an example of a Linking social capital, that form of capital that is sprung out through an evaluation of society as a whole.

33 Cf. Lennartsson, (1999). On the legal application of solving conflicts, see, for example, Sundin (1992); Österberg \& Sogner, (2000), and others. 
Brita and Måns were an ordinary married couple in Linköping. In the year of 1611 they appeared in court, apparently because of Måns' abuse of Brita. According to the protocol, Måns must stop his shameful and insulting name calling. Apparently it had happened many times before and everybody, that is Brita, of course, as well as their neighbours and the court, were tired of the anxiety and unsettledness he created. But instead of condemning Måns of the verbal abuse, or in any other way criminalizing his behaviour, the court made the parties shake hands, and along with the handshake make a promise that all that had been said and done, should from this day on be forgiven and forgotten. To settle the case, Brita got two appointed Guardians, and Måns got three. One can wonder how Brita felt upon this reconciliation. Perhaps it was a demand that was directly opposed to what she wanted, but from the point of view of the community it was naturally better if Måns and Brita could reestablish their household. The perspective of the whole probably meant that individual wishes were sometimes subordinated. One can also wonder about the appointed Guardians, what were their roles? The protocol unfortunately does not tell us much about that. However, the case illustrates how the municipal court worked on longer goals, and how it acted to achieve it. This is my interpretation:

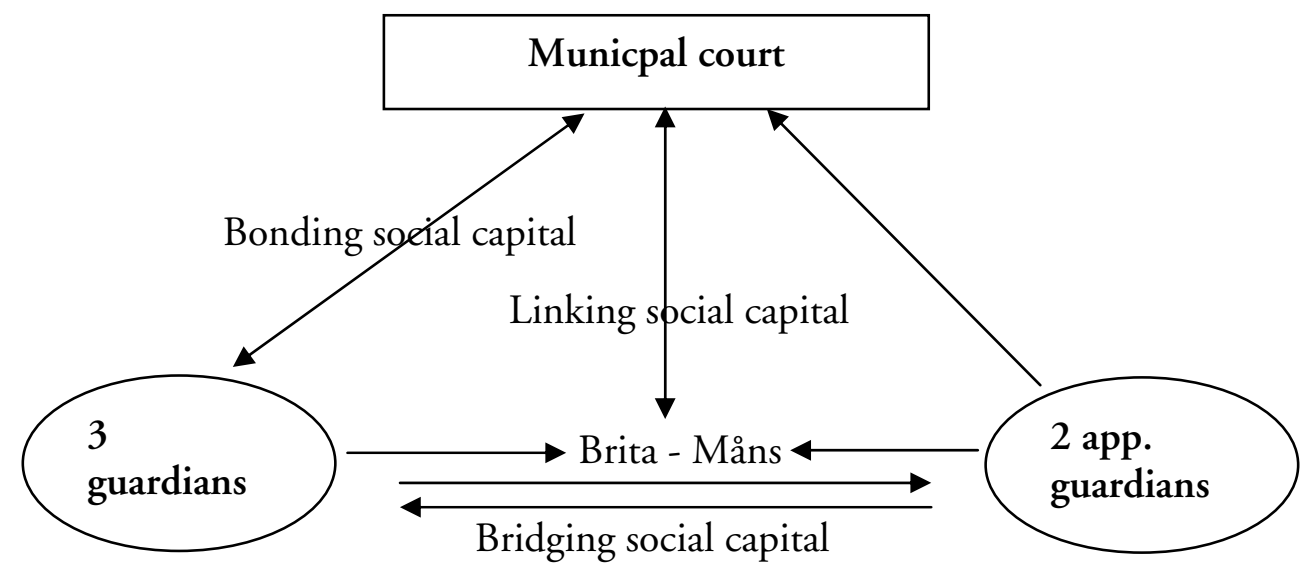

The arrangement can illustrate how resources were linking from the local formal institution - a linking social capital, to the spouses, through the appointed guardians who in doing it invested in their individual membership in the local elite, rather than acting out of care for the spouses, whom probably were not of his acquaintance. Further, in this process of negotiation with the parties, Brita and Måns, there was also built conditions for a trust between people who probably came from different social groups and assumable not acquainted - a bridging social capital. If the arrangement would succeed in getting them together, a bonding social capital would also be reestablished between the spouses. A few years later, Måns defended Brita in a slander case, which indicate that the attempt to reconciliate them actually succeeded. Perhaps the single appointed guardian wished to promote his interests in the network of local elite - the court - rather than acting out of care for Brita and Måns (who probably were not of his acquaintance). By assigning for the commission, and bringing it about, 
the appointed guardians invested in their relationships and enforced a bonding social capital

Brita's and Måns' marital happiness can hardly have been of personal concern to the mayor and the town council. When the municipal court restored to its previous role and function a household that was threatened with dissolution, I interpret this as something derived from a value placed upon the society as a whole, as part of longterm planning for Linköping's collective stability and order. In this way the town's leadership created a social capital by institutionally linking the strong and the weak groups. In the process, people with what appeared to be differing tasks and interests and who otherwise did not have much to do with one another, were bound together. R. D. Putnam argues that when people who really do not have too much in common are gathered in a common interest, trust can be created between people who otherwise would seldom have met. The result can be that people feel trust for more than those in their own group. Such activities among people create the prerequisites for reciprocal trust. Modern social scientists speak in terms of social capital. The mayor and the town councilmen in the municipal court in Linköping probably spoke about the conditions for maintaining order.

\section{Reliance on Institutions}

The municipal court and the church were arenas where the inhabitants of the town invested in and manifested capital of security. The life of the parish and the ceremonies were obviously important for people in both a religious and a social sense. The church's domain was a very important arena where the church through formation of the ceremonies could illustrate a good social order, just as for the members of the parish it was an arena for the manifestation of belonging and position in the community. The formation of the ceremonies of christening, marriage and the formal reception of women in church after childbirth served the interests of the women among the burghers. It was within the arena of the church that women primarily established and manifested honor. The court house was primarily for these men. At the same time that the practical activities of the local institutions were directed toward the collective, the men and women among the burghers appear to have been privileged groups: the functions and ceremonies of municipal court and the church served first of all their interests.

However, those in society with a presumedly low social capital also clearly valued the rituals of the town council and the church, and used the formal institutions to improve their conditions. Single mothers went to the cathedral chapter in order to force the fathers of their children to take responsibility for the child. ${ }^{34}$ The same was true of women who were abused in their homes. In spite of the fact that not only the 
law, but, obviously, even their partners were against them, they believed they could receive advice and help in the cathedral chapter and the municipal court. The conclusion can thus be drawn that there was great confidence in the formal institutions and that they were used by more than those who belonged to the upper social strata. The many ways of confirming honour showed that people believed in its power. People relied upon a handshake. They relied upon agreements. The same reliance was attributed to the transition rituals of the church. The woman who had again been received into the congregation after childbirth, for example, was not the same after the ceremony. It had changed her. The binding power of the ritual must be seen in terms of the need to be able to confirm decisions and to establish relations and positions in a time without a real written tradition. The written agreement has the same power and is built upon the same principles: to maintain norms and order a form for agreements must be found that can be relied upon. Therein lies its value. The confirmations of honour in the municipal court and the reacceptance of women in the church, for example, established in the same way agreements about social order and position. Rituals bound society together, they changed something, restored or manifested something. For a ritual to function in this way the sanction of officialdom is necessary. The town council and the church were thus arenas within which the inhabitants of the town demonstrated their confidence, manifested their honor and safeguarded their positions. $^{35}$

It is my understanding that when the residents of the town placed confidence in advice and justice in the formal institutions that trust was built up-with the neighbor and with the priest, with the mayor and with the town councilmen. When the individual burgher took care of his own personal capital of trust by performing duties as a guardian, it apparently provided effective fuel for realizing the goals of the town council.

Why did the municipal court forcibly bring about peace and harmony with the help of trusted men from the leading stratum of the city? A marriage restored to its original harmony probably provided assurance of a household that could provide for itself. With their marriage intact the proper order of the household and God's protection were also maintained. This should be seen as an expression of far-ranging notions about local society as a whole.

Annika Sandén is Ph.D. in History at Linköping University, Sweden. 


\section{References}

\section{The Regional State Archive in Vadstena}

Linköpings domkapitelsarkiv, LdA: domkapitelsprotokoll AI: 10 (1600-1621), [The Linköping Diocece Archive, Protocol AI: 10 (1600-1621)]

Inneliggande handlingar EIV: 133, [Acts and documents from EIV:133 The Linköping Diocece Archive ], (Här finns Nicolai Grubbs Lincop. Räkenskap för de personer, som hade taget skrift vid Linköpings domkyrka ifrån Philippi Jacobi, Ao 1616, - "skriftlistan".)

Lista över dem som inte tar nattvard i staden - odaterad, [List of those who did not take the Holy Communion, not dated]

Linköpings stadsarkiv, LstA, Linköpings rådsturätt AI: 1 (1609-1619), [The City Archive of Linköping, The Municipal Court, Protocol, AI:1 (1609-1619)]

\section{Litterature}

Bourdieu, P.,"The Forms of Capital", Handbook of Theory and Research for the Society of Education, (London 1986).

Dinges, M. "Die Ehre als Thema der Stadtgeschichte. Eine Semantik im Übergandg vom Ancien Régime zur Moderne", Zeitschrift für historische Forschung 16, (1989)

Harnesk, B. "Något om den lokala självstyrelsens problematic under 1500- och 1600talen", Individ och struktur i historisk belysning: festskrift till Sune Akerman (ed.) T. Ericsson \& G. Guillemot, (Umeå 1997).

Holmbäck, Å. \& Wessén, E. Magnus Erikssons Stadslag i nusvensk tolkning. (Lund 1966).

Jütte, R, Poverty and Diviance in Early modern Europe, Cambridge 1994.

Kamen, H., Early Modern European Society, (London 2000).

Lenman, B., \& G. Parker (eds.), Crime \& The Law. The Social History of Crime in Western Europe since 1500, (London 1980).

Lennartsson, M., I säng och säte. Relationer mellan kvinnor och män i 1600-talets Småland. (Lund 1999).

Lindstedt Cronberg, M., Synd och skam. Ogifta mödrar på svensk landsbygd 1680-1880, (Lund 1997).

McIntosh, M. K., Controlling Misbehaviour in England, 1370-1600, (Cambridge 1998).

McIntosh, M. K, "The Diversity of social capital in English communities, 1300-1640 (with a glance of modern Nigeria)", Rothberg (ed.) Patterns of social capital: stability and change in historical perspective, (Cambridge 2001). 
Ozment, S., When Fathers Ruled. Family Life in Reformation Europe, (Cambridge 1983).

Petri, L., "Oeconomia Christiana. Om Christeligh Husholdh och huad huario person eientligh effter gudz befolningh i huusholl tilkommer", Skrifter frän reformationstiden 5, (Uppsala 1897).

Pleijel. H, Hustavlans värld: kyrkligt folkliv i äldre tiders Sverige (Stockholm 1970).

Putnam, R. D., Making democracy work. civic traditions in modern Italy / Robert D. Putnam with Robert Leonardi and Raffaella Y. Nanetti, (Princeton1993).

Putnam, R. D, Bowling alone : the collapse and revival of American community. (New York 2000.

Roper, L., The Holy Household. Women and Morals in Reformation Augsburg, (Oxford 1991).

Rothstein, B., Democracies in flux : the evolution of social capital in contemporary society (ed.) Robert D Putnam, (Oxford 2002a)

Rothstein, B. \& S. Steinmo, Restructuring the welfare state : political institutions and policy change, (New York 2002b).

Runefelt, L., Hushålningens dygder. Affektlära, hushålningslära och ekonomiskt tänkande under svensk stormaktstid, (Stockholm 2001).

Sandén, A., "Handlingsnormer och rättskipning i det tidigmoderna Vadstena", Socialhistoria i Linköping nr 1, (Linköping 1997).

Sandén, A., Stadsgemenskapens resurser och villkor. Sambällssyn och välfärdsstrategier $i$ Linköping, 1600-1620 (The Towns sense of Community. Views of Society and Welfare Strategies in Linköping 1600-1620). (Linköping 2005).

Sandmo, E., "Aeren och aerekrenkelsen", Normer og social controll: ca 1550-1850 Domstolene i samspill med lokalsamfunnet Rapport II, det 22. nordiske historikermöte (Oslo 1994).

Sharpe, J. Crime in Early Modern England 1550-1750, (London 1984).

Stadin, K., Stånd och genus i stormaktstidens Sverige, (Stockholm 2004).

Sundin, J, För Gud, staten och folket. Brott och rättskipning i Sverige 1600-1840, Lund 1992.

Sundin, J., \& S. Willner, "Social stress, socialt kapital och hälsa. Välfärd och samhällsförändring i historia och nutid", Sambällsförändring och hälsa. Olika forskarperspektiv. (Stockholm 2003).

Szreter, S., "The state of social capital. Bringing back in power in politics and history", Theory and Society, (2003).

Woolcock, M., "Social capital and economic development: Toward a theoretical synthesis and policy framework", Theory and Society (1998:27).

Österberg, E., \& S. Sogner (eds.), S, People Meet the Law. Control and Conflicthandling in the Courts, (Oslo 2000).

Österberg, E., "Bönder och centralmakt I det tidigmoderna Sverige. Konflikt - kompromiss - politisk kultur" Scandia 1989:1 (Lund 1989). 